\title{
The effect of dietary potassium and sodium on performance, carcass traits, and nitrogen balance and excreta moisture in broiler chicken*
}

\author{
J. Koreleski ${ }^{1}$, S. Świątkiewicz and A. Arczewska \\ National Research Institute of Animal Production, \\ Department of Animal Nutrition and Feed Science \\ 32-083 Balice, Poland
}

(Received 20 July 2009; revised version 3 March 2010; accepted 7 May 2010)

\begin{abstract}
The aim of the $3 \times 3$ factorial experiment on broilers was to investigate the effect of high dietary levels of potassium $(\mathrm{K})$ and different levels of sodium $(\mathrm{Na})$ on chicken performance, carcass traits, dry matter content in excreta and nitrogen balance. Three hundred and sixty one-day-old Ross 308 chickens were allocated to 9 groups, in 5 replicates of 8 ( $4 \bigcirc^{\lambda}$ and 4 우). Chickens from 1 to 42 days old were kept in cages with wire floors to enable excreta collection, and were provided with water and feed ad libitum. The basal starter (days 1-14) and grower (days15-42) diets contained, as analysed, $1.73 \mathrm{~g}$ and $1.89 \mathrm{~g} \cdot \mathrm{kg}^{-1}$ chloride $(\mathrm{Cl}), 10.7 \mathrm{~g}$ and $10.8 \mathrm{~g} \mathrm{~K}$ and 0.69 and $0.94 \mathrm{~g} \mathrm{Na}$, respectively. Basal diets were supplemented with cations containing, as analysed, $12.2 / 11.8 \mathrm{~g}$ and $12.7 / 12.5 \mathrm{~g} \cdot \mathrm{kg}^{-1} \mathrm{~K}$ and $1.22 / 1.25 \mathrm{~g}$ and $1.68 / 1.61 \mathrm{~g} \cdot \mathrm{kg}^{-1} \mathrm{Na}$, for the starter/grower periods of feeding, respectively. The molar proportion of $\mathrm{Na}: \mathrm{K}$ in diets used in the experiment ranged from 0.09 to 0.27 in the starter diet and from 0.13 to 0.25 in the grower/finisher diet; the dietary electrolyte balance (DEB) values varied between 255 to 349 and 264 to 336 , respectively.

During the starter feeding period, body weight gain (BWG), feed intake (FI) and feed conversion ratio (FCR) in the chickens were positively affected by increasing the Na supplement. Throughout the feeding period, Na supplementation improved BWG, FI and FCR and production index values and increased carcass yield. The dry matter content of the excreta was negatively affected by the K level in the diet; the $12.7 \mathrm{~g} \mathrm{~K}$ dietary content, in particular, caused a higher moisture content.
\end{abstract}

\footnotetext{
"Supported by the Ministry of Science and Higher Education, Project No. N311 034734 (2261.5)

${ }^{1}$ Corresponding author: e-mail: jkoreles@izoo.krakow.pl
} 
The daily intake of nitrogen and nitrogen excretion grew when the dietary $\mathrm{Na}$ level was increased from 0.94 to 1.25 or $1.61 \mathrm{~g} \cdot \mathrm{kg}^{-1}$. The proportion of $\mathrm{N}$ retained to $\mathrm{N}$ intake decreased significantly when the dietary level of $\mathrm{Na}$ reached $1.61 \mathrm{~g}^{\cdot \mathrm{kg}^{-1}}$, as compared to the proportion at a level of $0.94 \mathrm{~g}$ $\mathrm{Na} \cdot \mathrm{kg}^{-1}$. Interaction between dietary $\mathrm{Na}$ and $\mathrm{K}$ levels for BWG and other indices of performance, and for nitrogen utilization, confirm a dietary reciprocal relationship for both electrolytes.

KEY WORDS: broiler chicken, potassium, sodium, dietary electrolyte balance, N-balance, performance, excreta

\section{INTRODUCTION}

Broiler diets based on plant components usually contain more potassium than diets including animal originated by-products. This is a result of high $\mathrm{K}$ content of plant protein sources and prohibited meat meals in feeding of poultry. NRC (1994) requirements for $\mathrm{K}$ in broilers are $3.0 \mathrm{~g} \cdot \mathrm{kg}^{-1}$ for both periods of feeding. More recently, the requirements for $\mathrm{K}$ in chickens for the periods of 8-21 and 22-42 days old are for a body weight gain of 6.28 and $7.14 \mathrm{~g} \mathrm{~kg}^{-1}$, respectively (Oliveira et al., 2005). Plant diets which markedly exceeded these levels of $\mathrm{K}$ may change the dietary electrolyte balance (DEB) and increase water intake and excreta moisture (Vieira and Lima, 2005). According to Mongin (1981), the DEB value, i.e. the difference between the sum of positive cations $\left(\mathrm{Na}^{+}+\mathrm{K}^{+}\right)$and negative anion $\left(\mathrm{Cl}^{-}\right)$ equivalents, in the diet is of great importance at high ambient temperature and as regards the heat stress undergone by chickens in hot parts of the world. Even in moderate climates however, there may well be several weeks of very hot weather each year. The Mongin electrolyte balance refers to dietary $\mathrm{K}^{+}, \mathrm{Na}^{+}$and $\mathrm{Cl}^{-}$at levels covering the nutritional requirements for chicken. It is not unlikely however that at a $\mathrm{K}$ content much higher than required in the diet, excreta humidity prevention and correction of DEB values may complicate reciprocal electrolyte proportions.

For diets with a higher content of $\mathrm{K}$, a question could be posed regarding the required levels of $\mathrm{Na}$ and $\mathrm{Cl}$. Using $\mathrm{Cl}$ adequate diets, Johnson and Karunajeewa (1985) found that for optimum growth rate equivalents, the $\mathrm{Na}: \mathrm{K}$ ratio in the broiler diet should not be allowed to fall below 0.5 , or to rise above 1.8 .

This paper investigates chicken performance, slaughter indices, dry matter content in excreta, and nitrogen balance (in order to confirm the performance and slaughter indices) in broilers fed high $\mathrm{K}$ and $\mathrm{Na}$ supplemented plant diets with a moderate and constant $\mathrm{Cl}$ content. The very low or adequate content of $\mathrm{Na}$ gives dietary electrolyte balance values from 255 to 349 . The molar Na:K ratio in this study fell to $0.09-0.27$, markedly below levels recommended by Johnson and Karunajeewa (1985) because of high dietary K content. 


\section{MATERIAL AND METHODS}

The Local Krakow Ethics Committee for Experiments with Animals approved all experimental procedures relating to the use of live animals. The trial was conducted during summer time with 360 Ross 308 broiler chickens of initial $40 \mathrm{~g}$ average body weight allocated to 9 groups in 5 replicates of

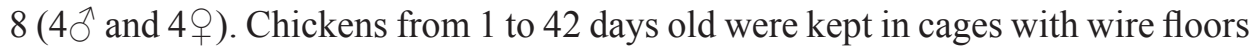
to enable excreta collection and were provided with water and feed ad libitum.

The basal starter (days 1-14) and grower (days 15-42) diets (Table 1) were of the grain-soyabean meal type (without animal originated meals), and contained chloride at a moderate level of $1.73 \mathrm{~g}$ and $1.89 \mathrm{~g} \cdot \mathrm{kg}^{-1}$, respectively. The natural $\mathrm{K}$ level in the basal diet was relatively high, and was even enlarged by $\mathrm{K}$ salt additives. A $3 \times 3$ factorial arrangement, with three dietary levels of $K$ and three levels of $\mathrm{Na}$, was used. The diets were either supplemented with $\mathrm{K}$ hydrogen

Table 1. Composition of basal diets, $\mathrm{g} \cdot \mathrm{kg}^{-1}$

\begin{tabular}{|c|c|c|}
\hline Item & $\begin{array}{c}\text { Starter diet } \\
1-14 \text { days }\end{array}$ & $\begin{array}{c}\text { Grower-finisher diet } \\
15-42 \text { days }\end{array}$ \\
\hline \multicolumn{3}{|l|}{ Component } \\
\hline maize (grinded) & 565.01 & 602.79 \\
\hline soyabean meal & 369 & 320 \\
\hline rapeseed oil & 25 & 36 \\
\hline limestone & 17.4 & 17.53 \\
\hline monocalcium phosphate & 14.4 & 13.05 \\
\hline $\mathrm{NaCl}$ & 1.37 & 2.04 \\
\hline $\mathrm{NH}_{4} \mathrm{Cl}$ & 0.51 & 0.54 \\
\hline DL-methionine (99\%) & 2.31 & 2.12 \\
\hline L-lysine $\mathrm{HCl}(78 \%)$ & - & 0.93 \\
\hline vitamin-mineral premix ${ }^{1}$ & 5.0 & 5.0 \\
\hline \multicolumn{3}{|c|}{ Nutrients content in basal diet, $g \mathrm{~g} \cdot \mathrm{kg}^{-1}$} \\
\hline crude protein ${ }^{2}$ & 220 & 203 \\
\hline $\mathrm{ME}, \mathrm{MJ}^{3}$ & 12.5 & 13.0 \\
\hline Lys & 12.0 & 11.5 \\
\hline Met & 5.5 & 5.2 \\
\hline $\mathrm{Ca}$ & 9.4 & 9.2 \\
\hline $\mathrm{P}$ available & 4.3 & 4.0 \\
\hline $\mathrm{K}^{2}$ & 10.72 & 10.80 \\
\hline $\mathrm{Na}^{2}$ & 0.69 & 0.94 \\
\hline $\mathrm{Cl}^{2}$ & 1.73 & 1.89 \\
\hline \multicolumn{3}{|c|}{ 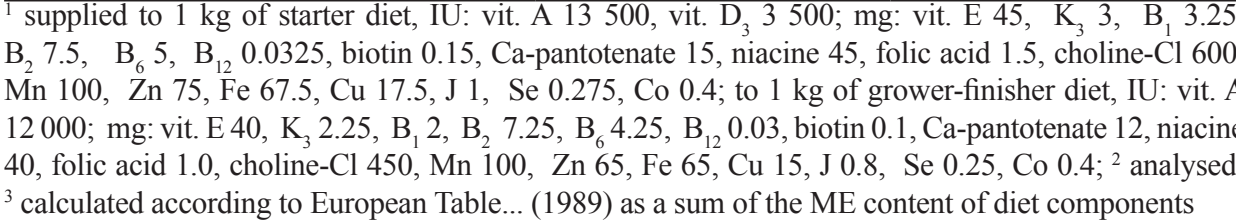 } \\
\hline
\end{tabular}


carbonate $\left(\mathrm{KHCO}_{3}\right)$ and $\mathrm{Na}$ hydrogen carbonate $\left(\mathrm{NaHCO}_{3}\right)$, or remained non supplemented, in order to contain, as analysed: 10.7/10.8 g, 12.2/11.8 $\mathrm{g}$ and $12.7 / 12.5 \mathrm{~g} \cdot \mathrm{kg}^{-1} \mathrm{~K}$ and $0.69 / 0.94 \mathrm{~g}, 1.22 / 1.25 \mathrm{~g}$ and $1.68 / 1.61 \mathrm{~g} \cdot \mathrm{kg}^{-1} \mathrm{Na}$, for the starter/grower feeding periods, respectively (Table 2). The $\mathrm{K}$ and $\mathrm{Na}$ content was analysed by atomic absorption spectrometry (ISO6869:2000). The $\mathrm{Cl}$ content was calculated from water soluble $\mathrm{Cl}$, estimated by Volhard's silver nitrate titration method (1874).

Table 2. Scheme of dietary electrolyte balance values DEB, $\mathrm{mEq} \cdot \mathrm{kg}^{-1}$ in diets

\begin{tabular}{lccc}
\hline \multirow{2}{*}{ K level in the diet, $\mathrm{g} \cdot \mathrm{kg}^{-1}$} & \multicolumn{3}{c}{ Na level in the diet, $\mathrm{g} \cdot \mathrm{kg}^{-1}, 1-14$ days } \\
\cline { 2 - 4 } & $0.69\left(\mathrm{Na}^{+} \mathrm{VL}\right)$ & $1.22\left(\mathrm{Na}^{+} \mathrm{L}\right)$ & $1.68\left(\mathrm{Na}^{+} \mathrm{A}\right)$ \\
\hline 10.7 & 255 & 278 & 298 \\
12.2 & 293 & 316 & 336 \\
12.7 & 306 & 329 & 349
\end{tabular}

\begin{tabular}{lccc}
\hline \multirow{2}{*}{$\mathrm{K}$ level in the diet, $\mathrm{g} \cdot \mathrm{kg}^{-1}$} & \multicolumn{3}{c}{ Na level in the diet, $\mathrm{g} \cdot \mathrm{kg}^{-1}, 15-42$ days } \\
\cline { 2 - 4 } & $0.94\left(\mathrm{Na}^{+} \mathrm{VL}\right)$ & $1.25\left(\mathrm{Na}^{+} \mathrm{L}\right)$ & $1.61\left(\mathrm{Na}^{+} \mathrm{A}\right)$ \\
\hline 10.8 & 264 & 277 & 293 \\
11.8 & 291 & 304 & 320 \\
12.5 & 307 & 321 & 336 \\
\hline
\end{tabular}

The body weight (BW) and feed intake (FI) in the chickens were measured and mortality was registered. Body weight gain (BWG), feed conversion ratio (FCR) were calculated for the starter period, the grower period and the entire feeding period. The production index (PI) was calculated for entire feeding period:

$$
\mathrm{PI}=[\text { body weight }(\mathrm{kg}) \times \operatorname{survival}(\%) / \text { age }(42 \mathrm{~d} .) \times \mathrm{FCE}(\mathrm{kg})] \times 100
$$

At 13 and 41 days old, samples of excreta were collected from the dropping tray immediately after excretion, hermetically packed and analysed for dry matter (DM) content (AOAC, 1990).

During the first 5 days of the chickens' $4^{\text {th }}$ week the feed consumed was measured and a total collection of excreta on droppings trays from 5 replicates of 8 chickens in each group was carried out. Feathers were removed from excreta trays and the excreta was weighted each day and stored at $-20^{\circ} \mathrm{C}$. At the end of balance estimation, after thawing, the excreta were weighted again, homogenized and representative samples for the analysis of nitrogen content were taken. $\mathrm{N}$ contents in diets and in excreta were estimated by the Kjeldahl method (AOAC, 1990), using Kjeltec Auto 1030, Tecator. N-balance indices were calculated taking into account amounts of $\mathrm{N}$ ingested and $\mathrm{N}$ excreted (Becker and Harnish, 1958).

At the end of the experiment and after $12 \mathrm{~h}$ of starvation all chickens were weighed and 4 representative cockerels and 4 hens were chosen from each group with live body weights close to the group average, marked with number signs and 
decapitated. Chickens were ploughed, the intestines and crop were removed and carcasses stored overnight in $4^{\circ} \mathrm{C}$. The mass of the cooled carcasses with edible giblets (gizzard, liver, heart) were estimated and carcass yield calculated (Ziołecki and Doruchowski, 1989). The breast muscles and abdominal fat and livers and hearts were excised and weighted. The breast muscles and abdominal fat contents were expressed as $\%$ in carcass. The relative weight of liver and heart as $\%$ of liveweight were calculated.

The data were subjected to a two-way factorial analysis of variance. The significance of differences between means was determined by Duncan's multiple range test and differences were considered significant at $\mathrm{P} \leq 0.05$. Statistical analyses were performed using Statistica 5.0 PL software (Statsoft Inc.).

\section{RESULTS}

As compared to broiler requirements, the dietary $\mathrm{Na}$ levels used in this experiment (Tables 1 and 2) were very low $\left(\mathrm{Na}^{+} \mathrm{VL}\right)$, low $\left(\mathrm{Na}^{+} \mathrm{L}\right)$ or adequate $\left(\mathrm{Na}^{+} \mathrm{A}\right)$.

During the starter feeding period, the BWG, FI and FCR in chickens were positively affected by increasing the Na supplement $(\mathrm{P} \leq 0.001)$, whereas the effect on performance of increasing the $\mathrm{K}$ level in the diet was small and statistically not significant (Table 3). Similar effects were observed in the grower feeding period (Table 3), but at that time, the increasing level of $\mathrm{K}$ significantly decreased the chicken's BWG. The experimental factors had no effect on the mortality throughout the feeding period (Table 3), but Na supplementation improved BWG, FI, FCR and PI values $(\mathrm{P} \leq 0.001)$. Significant interaction $(\mathrm{P} \leq 0.001)$ may confirm the relation of $\mathrm{K}$ and $\mathrm{Na}$ dietary level in the case of $\mathrm{BWG}$ and feed intake. The highest BWG values, the largest FI and the best FCR in the first feeding period were observed in chickens fed diets containing higher $\mathrm{K}^{+}, \mathrm{Na}^{+} \mathrm{L}$ and $\mathrm{Na}^{+} \mathrm{A}$ content and with DEB values from 329 to 336 (Table 2). The molar proportion of Na:K in the diets used in the experiment ranged from 0.09 to 0.27 in the starter diet and from 0.13 to 0.25 in the grower/finisher one. 
Table 3. The performance of chickens

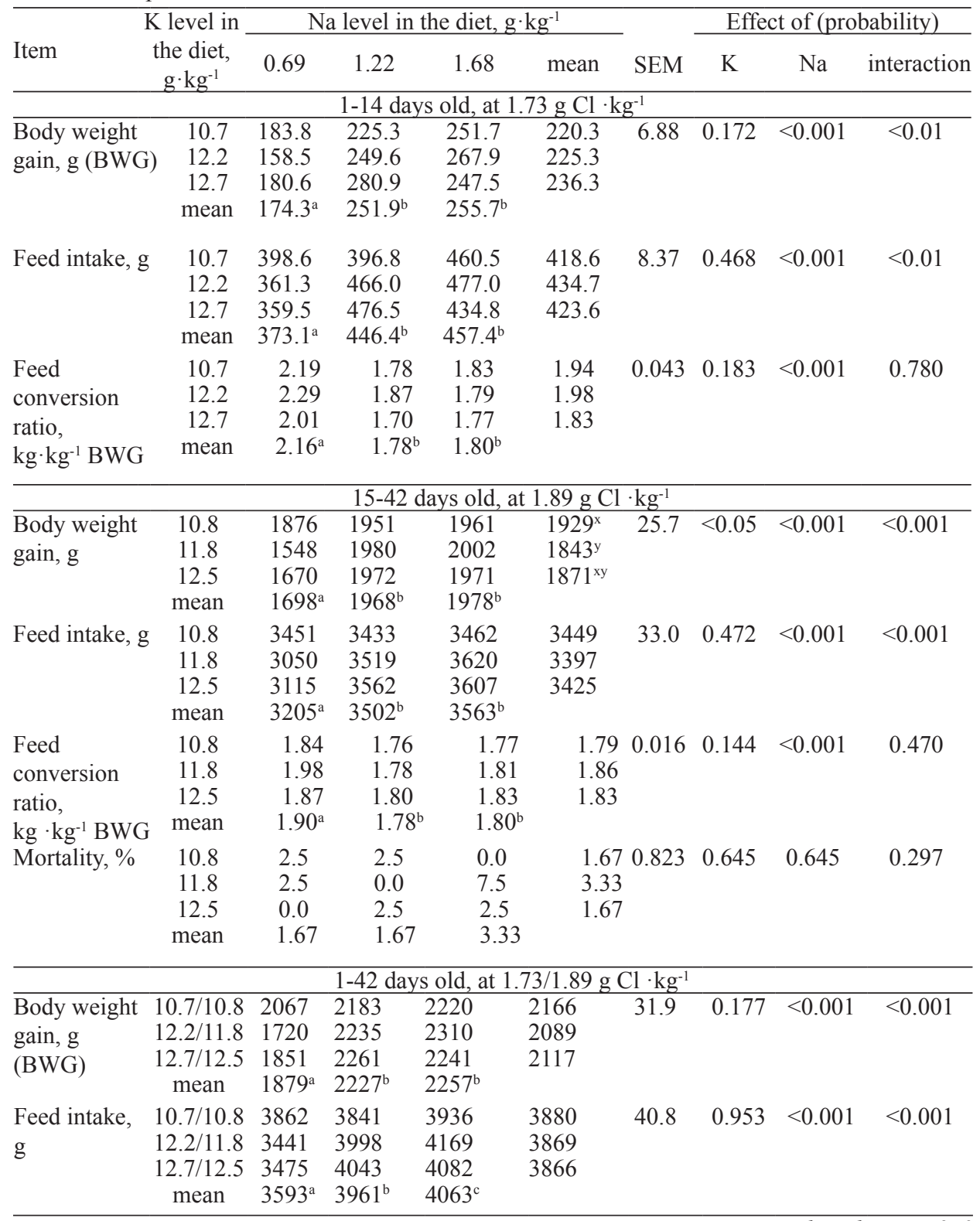


Table 3. The performance of chickens

continued

\begin{tabular}{|c|c|c|c|c|c|c|c|c|c|}
\hline \multirow[b]{2}{*}{ Item } & \multirow{2}{*}{$\begin{array}{l}\mathrm{K} \text { level in } \\
\text { the diet, } \\
\mathrm{g} \cdot \mathrm{kg}^{-1}\end{array}$} & \multicolumn{4}{|c|}{$\mathrm{Na}$ level in the diet, $\mathrm{g} \cdot \mathrm{kg}^{-1}$} & \multirow[b]{2}{*}{ SEM } & \multicolumn{3}{|c|}{ Effect of (probability) } \\
\hline & & 0.69 & 1.22 & 1.68 & mean & & $\mathrm{K}$ & $\mathrm{Na}$ & interaction \\
\hline \multirow{3}{*}{$\begin{array}{l}\text { Feed con- } \\
\text { version, } \\
\mathrm{kg} \cdot \mathrm{kg}^{-1} \\
\mathrm{BWG}\end{array}$} & $10.7 / 10.8$ & 1.87 & 1.76 & 1.77 & 1.80 & \multirow[t]{3}{*}{0.0156} & \multirow[t]{3}{*}{0.113} & \multirow[t]{3}{*}{$<0.001$} & \multirow[t]{3}{*}{0.349} \\
\hline & $12.2 / 11.8$ & 2.01 & 1.79 & 1.80 & 1.87 & & & & \\
\hline & $\begin{array}{c}12.7 / 12.5 \\
\text { mean }\end{array}$ & $\begin{array}{l}1.88 \\
1.92^{\mathrm{a}}\end{array}$ & $\begin{array}{l}1.79 \\
1.78^{\mathrm{b}}\end{array}$ & $\begin{array}{l}1.82 \\
1.80^{\mathrm{b}}\end{array}$ & 1.83 & & & & \\
\hline Mortality, $\%$ & $\begin{array}{c}10.7 / 10.8 \\
12.2 / 11.8 \\
12.7 / 12.5 \\
\text { mean }\end{array}$ & $\begin{array}{l}2.5 \\
2.5 \\
0.0 \\
1.67\end{array}$ & $\begin{array}{l}2.5 \\
0.0 \\
2.5 \\
1.67\end{array}$ & $\begin{array}{l}0.0 \\
7.5 \\
2.5 \\
3.33\end{array}$ & $\begin{array}{l}1.67 \\
3.33 \\
1.67\end{array}$ & 0.823 & 0.645 & 0.645 & 0.297 \\
\hline $\begin{array}{l}\text { Production } \\
\text { Index, } \\
\text { (points) }\end{array}$ & $\begin{array}{c}10.7 / 10.8 \\
12.2 / 11.8 \\
12.7 / 12.5 \\
\text { mean }\end{array}$ & $\begin{array}{l}258 \\
201 \\
235 \\
231^{\mathrm{a}}\end{array}$ & $\begin{array}{l}288 \\
298 \\
294 \\
293^{b}\end{array}$ & $\begin{array}{l}298 \\
284 \\
286 \\
290^{\mathrm{b}}\end{array}$ & $\begin{array}{l}281 \\
261 \\
272\end{array}$ & 6.33 & 0.209 & $<0.001$ & 0.214 \\
\hline
\end{tabular}

The DM content of excreta (Table 4) was negatively affected by the K level in the diet; in particular, the highest dietary $\mathrm{K}^{+}$content increased moisture content $(\mathrm{P} \leq 0.001)$. In contrast, Na supplementation had no effect on the dry matter content of excreta, but gives and increased carcass yield $(\mathrm{P}<0.05)$ in chickens (Table 5). A statistically unconfirmed tendency for a positive effect on carcass yield was also found in the case of added K. Dietary levels of $\mathrm{K}^{+}$and $\mathrm{Na}^{+}$had no significant effect on breast meat yield, abdominal fat content in the carcass and relative weights of liver and heart (Table 5).

Table 4. Dry matter in excreta, \%

\begin{tabular}{|c|c|c|c|c|c|c|c|c|c|}
\hline \multirow[b]{2}{*}{ Item } & \multirow{2}{*}{$\begin{array}{c}\mathrm{K} \text { level in } \\
\text { the diet } \\
\mathrm{g} \cdot \mathrm{kg}^{-1}\end{array}$} & \multicolumn{4}{|c|}{$\mathrm{Na}$ level in the diet, $\mathrm{g} \cdot \mathrm{kg}^{-1}$} & \multirow[b]{2}{*}{ SEM } & \multicolumn{3}{|c|}{ Effect of (probability) } \\
\hline & & $\left(\mathrm{Na}^{+} \mathrm{VL}\right)$ & $\left(\mathrm{Na}^{+} \mathrm{L}\right)$ & $\left(\mathrm{Na}^{+} \mathrm{A}\right)$ & mean & & K & $\mathrm{Na}$ & interaction \\
\hline \multirow{4}{*}{$\begin{array}{l}\text { Starter } \\
\text { period }\end{array}$} & 10.7 & 17.4 & 18.0 & 18.4 & $17.9^{\mathrm{a}}$ & \multirow[t]{4}{*}{0.199} & \multirow[t]{4}{*}{$<0.001$} & \multirow[t]{4}{*}{0.078} & \multirow[t]{4}{*}{$<0.05$} \\
\hline & 12.2 & 16.2 & 17.7 & 16.9 & $16.9^{\mathrm{b}}$ & & & & \\
\hline & 12.7 & 16.2 & 16.2 & 14.9 & $15.8^{\mathrm{c}}$ & & & & \\
\hline & mean & 16.6 & 17.3 & 16.7 & & & & & \\
\hline \multirow{4}{*}{$\begin{array}{l}\text { Grower } \\
\text { period }\end{array}$} & 10.8 & 18.2 & 16.5 & 15.6 & $16.7^{\mathrm{a}}$ & \multirow[t]{4}{*}{0.245} & \multirow[t]{4}{*}{$<0.001$} & \multirow[t]{4}{*}{0.198} & \multirow[t]{4}{*}{0.175} \\
\hline & 11.8 & 15.5 & 15.8 & 15.9 & $15.7^{\mathrm{a}}$ & & & & \\
\hline & 12.5 & 15.0 & 14.5 & 14.4 & $14.6^{\mathrm{b}}$ & & & & \\
\hline & mean & 16.2 & 15.6 & 15.3 & & & & & \\
\hline
\end{tabular}


Table 5. Results of slaughter analysis

\begin{tabular}{|c|c|c|c|c|c|c|c|c|c|}
\hline \multirow[b]{2}{*}{ Item } & \multirow{2}{*}{$\begin{array}{c}\mathrm{K} \text { level } \\
\text { in the diet } \\
\mathrm{g} \cdot \mathrm{kg}^{-1}\end{array}$} & \multicolumn{4}{|c|}{$\mathrm{Na}$ level in the diet, $\mathrm{g} \cdot \mathrm{kg}^{-1}$} & \multirow{2}{*}{ SEM } & \multicolumn{3}{|c|}{ Effect (probability) } \\
\hline & & $\left(\mathrm{Na}^{+} \mathrm{VL}\right)$ & $\left(\mathrm{Na}^{+} \mathrm{L}\right)$ & $\left(\mathrm{Na}^{+} \mathrm{A}\right)$ & mean & & $\mathrm{K}$ & $\mathrm{Na}$ & interaction \\
\hline \multirow{4}{*}{$\begin{array}{l}\text { Carcass } \\
\text { yield, \% }\end{array}$} & 10.8 & 74.9 & 75.6 & 76.2 & 75.4 & \multirow[t]{4}{*}{0.226} & \multirow[t]{4}{*}{0.221} & \multirow[t]{4}{*}{$<0.01$} & \multirow[t]{4}{*}{0.393} \\
\hline & 11.8 & 74.5 & 77.3 & 75.9 & 76.1 & & & & \\
\hline & 12.5 & 75.2 & 76.3 & 76.2 & 76.2 & & & & \\
\hline & mean & $74.8^{\mathrm{a}}$ & $76.4^{\mathrm{b}}$ & $76.4^{\mathrm{b}}$ & & & & & \\
\hline \multirow{4}{*}{$\begin{array}{l}\text { Breast meat } \\
\text { yield, } \% \text { of } \\
\text { carcass }\end{array}$} & 10.8 & 26.1 & 26.7 & 26.6 & 26.5 & \multirow[t]{4}{*}{0.213} & \multirow[t]{4}{*}{0.060} & \multirow[t]{4}{*}{0.260} & \multirow[t]{4}{*}{0.517} \\
\hline & 11.8 & 25.1 & 24.7 & 26.3 & 25.4 & & & & \\
\hline & 12.5 & 24.9 & 26.1 & 25.8 & 25.6 & & & & \\
\hline & mean & 25.4 & 25.8 & 26.2 & & & & & \\
\hline \multirow{4}{*}{$\begin{array}{l}\text { Abdominal } \\
\text { fat content, } \\
\% \text { of } \\
\text { carcass }\end{array}$} & 10.8 & 1.89 & 1.55 & 1.57 & 1.67 & \multirow[t]{4}{*}{0.0710} & \multirow[t]{4}{*}{0.611} & \multirow[t]{4}{*}{0.779} & \multirow[t]{4}{*}{0.151} \\
\hline & 11.8 & 1.66 & 1.65 & 1.32 & 1.55 & & & & \\
\hline & 12.5 & 1.32 & 1.32 & 1.85 & 1.49 & & & & \\
\hline & mean & 1.63 & 1.51 & 1.58 & & & & & \\
\hline \multirow{4}{*}{$\begin{array}{l}\text { Relative } \\
\text { weight of } \\
\text { liver, \% of } \\
\text { liveweight }\end{array}$} & 10.8 & 2.20 & 1.91 & 2.02 & 2.03 & \multirow[t]{4}{*}{0.0273} & \multirow[t]{4}{*}{0.921} & \multirow[t]{4}{*}{0.172} & \multirow[t]{4}{*}{0.473} \\
\hline & 11.8 & 2.05 & 1.98 & 1.96 & 2.01 & & & & \\
\hline & 12.5 & 2.01 & 2.02 & 2.05 & 2.02 & & & & \\
\hline & mean & 2.09 & 1.97 & 2.00 & & & & & \\
\hline \multirow{4}{*}{$\begin{array}{l}\text { Relative } \\
\text { weight of } \\
\text { heart, \% of } \\
\text { liveweight }\end{array}$} & 10.8 & 0.438 & 0.464 & 0.468 & 0.457 & \multirow{4}{*}{0.0081} & \multirow[t]{4}{*}{0.246} & \multirow[t]{4}{*}{0.217} & \multirow[t]{4}{*}{0.317} \\
\hline & 11.8 & 0.494 & 0.444 & 0.532 & 0.488 & & & & \\
\hline & 12.5 & 0.470 & 0.455 & 0.464 & 0.463 & & & & \\
\hline & mean & 0.465 & 0.454 & 0.488 & & & & & \\
\hline
\end{tabular}

$\overline{\mathrm{a}, \mathrm{b}}$ - values in the rows with different letters differ significantly $(\mathrm{P} \leq 0.05)$

In balance estimations, the daily intake of nitrogen grew when the dietary $\mathrm{Na}$ level was increased from 0.94 to $1.61 \mathrm{~g} \cdot \mathrm{kg}^{-1}$. Nitrogen excretion grew in a manner corresponding to the $\mathrm{Na}$ intake $(\mathrm{P}<0.05)$. The proportion of $\mathrm{N}$ retained $\mathrm{N}$ intake markedly decreased $(\mathrm{P}<0.05)$ when the dietary level of $\mathrm{Na}$ reached $1.61 \mathrm{~g}^{\cdot \mathrm{kg}^{-1}}$, as compared to the proportion at Na level of $0.94 \mathrm{~g} \cdot \mathrm{kg}^{-1}$ of diet (Table 6) to manner corresponding to the $\mathrm{Na}$ intake $(\mathrm{P}<0.05)$. The proportion of $\mathrm{N}$ retained to $\mathrm{N}$ intake markedly decreased $(\mathrm{P}<0.05)$ when the dietary level of $\mathrm{Na}$ reached $1.61 \mathrm{~g} \cdot \mathrm{kg}-1$, as compared to the proportion at Na level of $0.94 \mathrm{~g} \cdot \mathrm{kg}-1$ of diet (Table 6). 
Table 6. Nitrogen balance

\begin{tabular}{|c|c|c|c|c|c|c|c|c|c|}
\hline \multirow[b]{2}{*}{ Item } & \multirow{2}{*}{$\begin{array}{c}\text { K level } \\
\text { in the diet } \\
\mathrm{g} \cdot \mathrm{kg}^{-1}\end{array}$} & \multicolumn{4}{|c|}{$\mathrm{Na}$ level in the diet, $\mathrm{g} \cdot \mathrm{kg}^{-1}$} & \multirow[b]{2}{*}{ SEM } & \multicolumn{3}{|c|}{ Effect of (probability) } \\
\hline & & $\left(\mathrm{Na}^{+} \mathrm{VL}\right)$ & $\left(\mathrm{Na}^{+} \mathrm{L}\right)$ & $\left(\mathrm{Na}^{+} \mathrm{A}\right)$ & mean & & $\mathrm{K}$ & $\mathrm{Na}$ & interaction \\
\hline \multirow{4}{*}{$\begin{array}{l}\mathrm{N} \text { intake, } \\
\mathrm{mg} / \text { bird per } \\
\text { day }\end{array}$} & 10.8 & 4522 & 4467 & 4475 & 4498 & \multirow[t]{4}{*}{53.5} & \multirow[t]{4}{*}{0.618} & $<0.01$ & \multirow[t]{4}{*}{0.061} \\
\hline & 11.8 & 4022 & 4512 & 4641 & 4392 & & & & \\
\hline & 12.5 & 4078 & 4612 & 4719 & 4470 & & & & \\
\hline & mean & $4218^{a}$ & $4530^{\mathrm{b}}$ & $4612^{b}$ & & & & & \\
\hline \multirow{4}{*}{$\begin{array}{l}\mathrm{N} \text { excretion, } \\
\mathrm{mg} / \text { bird per } \\
\text { day }\end{array}$} & 10.8 & 1596 & 1870 & 2168 & 1878 & \multirow[t]{4}{*}{38.6} & \multirow[t]{4}{*}{0.170} & $<0.001$ & \multirow[t]{4}{*}{0.066} \\
\hline & 11.8 & 1621 & 1976 & 2106 & 1901 & & & & \\
\hline & 12.5 & 1698 & 1843 & 1783 & 1775 & & & & \\
\hline & mean & $1638^{a}$ & $1897^{b}$ & $2019^{b}$ & & & & & \\
\hline \multirow{4}{*}{$\begin{array}{l}\mathrm{N} \text { retention, } \\
\mathrm{mg} / \text { bird per } \\
\text { day }\end{array}$} & 10.8 & 2956 & 2596 & 2306 & 2620 & \multirow[t]{4}{*}{56.2} & \multirow[t]{4}{*}{0.252} & 0.897 & \multirow[t]{4}{*}{$<0.01$} \\
\hline & 11.8 & 2401 & 2536 & 2535 & 2491 & & & & \\
\hline & 12.5 & 2380 & 2769 & 2936 & 2695 & & & & \\
\hline & mean & 2579 & 2634 & 2593 & & & & & \\
\hline \multirow{4}{*}{$\begin{array}{l}\mathrm{N} \text { retained, } \\
\% \text { of } \mathrm{N} \\
\text { intake }\end{array}$} & 10.8 & 64.6 & 58.1 & 51.6 & 58.1 & \multirow[t]{4}{*}{0.83} & \multirow[t]{4}{*}{0.150} & $<0.05$ & \multirow[t]{4}{*}{$<0.01$} \\
\hline & 11.8 & 59.6 & 56.1 & 54.6 & 56.8 & & & & \\
\hline & 12.5 & 58.3 & 59.8 & 62.1 & 60.1 & & & & \\
\hline & mean & $60.8^{\mathrm{b}}$ & $58.0^{\mathrm{ab}}$ & $56.1^{\mathrm{a}}$ & & & & & \\
\hline
\end{tabular}

$\overline{\mathrm{a}, \mathrm{b}}$ - values in the rows with different letters differ significantly $(\mathrm{P} \leq 0.05)$

\section{DISCUSSION}

Electrolyte requirements and performance. For the first period of feeding, NRC (1994) recommends $3.0 \mathrm{~g} \mathrm{~K}$ and $2.0 \mathrm{~g} \mathrm{Na}$ and $2.0 \mathrm{~g} \mathrm{Cl}$ per $\mathrm{kg}$ of diet. For best weight gain and feed conversion, Borges et al. (2007) have suggested a requirement of $3.5 \mathrm{~g} \mathrm{Na}$ and $3.66 \mathrm{~g} \cdot \mathrm{Cl} \cdot \mathrm{kg}^{-1}$ as recommended values at $7.45 \mathrm{~g} \cdot \mathrm{kg}^{-1} \mathrm{~K}$ and at a value of $240 \mathrm{mEq} / \mathrm{kg}$ (DEB), irrespective of ambient temperature. In contrast, Murakami et al. (1997) suggested that, at K $10.1 \mathrm{~g} \cdot \mathrm{kg}^{-1}$, $\mathrm{Na}$ requirements were no more than $2.0 \mathrm{~g}$ up to 21 days old chickens.

In an experiment reported by Borgatti et al. (2004), a high weight gain was found at $1.8 \mathrm{~g} \cdot \mathrm{Na}^{+}, 12.2 \mathrm{~g} \cdot \mathrm{K}^{+}$and $2.2 \mathrm{~g} \cdot \mathrm{Cl} \cdot \mathrm{kg}^{-1}$ of diet and at a DEB value of 330. In our experiment the highest BWG values, the largest FI and the best FCR in the first feeding period were observed in chickens fed diets containing higher $\mathrm{K}^{+}\left(12.2\right.$ and $\left.12.7 \mathrm{~g} \cdot \mathrm{kg}^{-1}\right), \mathrm{Na}^{+} \mathrm{L}$ and $\mathrm{Na}^{+} \mathrm{A}\left(1.22\right.$ and $\left.1.68 \mathrm{~g} \cdot \mathrm{kg}^{-1}\right)$ content and with DEB values from 329 to 349 .

According to suggestions of specific cation effects independent of DEB(Johnson and Karunajeewa, 1985), the Na:K molar ratios in the diets used in our experiment were generally low. In diets with a high level of $\mathrm{K}$, that ratio for adequate BWG 
in chickens reached values at 0.16 to 0.27 and 0.17 to 0.25 , for FCR 0.16 to 0.19 and 0.17 to 0.20 in the first and second feeding periods, respectively. The values presented fall much lower than the $0.5 \mathrm{Na}: \mathrm{K}$ ratio established as a minimum for growth in Johnson and Karunajeewa (1985) experiment. This could suggest that in high $\mathrm{K}$ and $\mathrm{Cl}$-adequate diets, the $\mathrm{Na}: \mathrm{K}$ ratio may be markedly lower for effective chicken performance in first period of feeding. The poor performance for the $\mathrm{Na}^{+} \mathrm{VL}$ diet may confirm the Na deficiency status of a low $\mathrm{Na}$ diet for chickens.

In the second feeding period Murakami et al. $(1997,2001)$ have suggested the requirement for chicken as being $1.5 \mathrm{~g} \mathrm{Na}$ and $2.3 \mathrm{~g} \mathrm{Cl} \cdot \mathrm{kg}^{-1}$ at a DEB of between $249-261 \mathrm{mEq} / \mathrm{kg}$ and a K level of $9.6 \mathrm{~g} \cdot \mathrm{kg}^{-1}$. NRC (1994) recommends $1.5 \mathrm{~g} \mathrm{Na}^{+}$; $3.0 \mathrm{~g} \cdot \mathrm{K}^{+}$and $1.5 \mathrm{~g} \mathrm{Cl}^{-} \cdot \mathrm{kg}^{-1}$ of diet. For older broiler chickens, Borges et al. (2007) have found $3.5 \mathrm{~g} \cdot \mathrm{Na}^{+} ; 6.66 \mathrm{~g} \cdot \mathrm{K}^{+}$and $2.94 \mathrm{~g} \cdot \mathrm{Cl}^{-} \mathrm{kg}^{-1}$ give the best weight gain and feed conversion in the tropics. Oliveira et al. (2005) estimated 6.3, 7.1 and $8.0 \mathrm{~g}$ of dietary $\mathrm{K}$ as a requirement for that macroelement to give broiler growth in the starter, grower and finisher feeding periods with a constant $\mathrm{Na}$ and $\mathrm{Cl}$ content in the diet.

The dietary $\mathrm{Na}$ levels in present experiment were very low $\left(\mathrm{Na}^{+} \mathrm{VL}\right)$, low $\left(\mathrm{Na}^{+} \mathrm{L}\right)$ or adequate $\left(\mathrm{Na}^{+} \mathrm{A}\right)$, as compared to broiler requirements (NRC, 1994; Murakami et al., 1997, 2001; Borges et al., 2007), whereas the dietary K levels used were relatively high (Oliveira et al., 2005). A significant improvement of BWG, FI and FCR was noted when the Na level in grower/finisher diet increased from 0.94 to $1.25 \mathrm{~g} \cdot \mathrm{kg}^{-1}$. A further increase of $\mathrm{Na}$ level in the diet (to $1.6 \mathrm{~g} \cdot \mathrm{kg}^{-1}$ ) resulted in only a statistically unconfirmed tendency towards improved chicken performance. On the other hand, elevated dietary K level had a tendency to cause a deterioration in performance, but at $11.8 \mathrm{~K}$ and $1.61 \mathrm{Na}$, the BWG reached its highest value. Similar results were obtained across the entire period of the experiment (1-42 d). BWG and FCR values were significantly improved between chickens fed $\mathrm{Na}^{+} \mathrm{VL}$ and $\mathrm{Na}^{+} \mathrm{L}$ diets. If further elevation, from $\mathrm{Na}^{+} \mathrm{L}$ to $\mathrm{Na}^{+} \mathrm{A}$, improved performance, this effect of $\mathrm{Na}$ was not significantly confirmed. Only in the case of FI was the effect of increasing the $\mathrm{Na}$ level to $\mathrm{Na}^{+} \mathrm{A}$ level significantly confirmed. Throughout the feeding period the poor performance for the $\mathrm{Na}^{+} \mathrm{VL}$ diet may confirm the Na deficiency status of a low Na diet $\left(0.69-0.94 \mathrm{~g} \cdot \mathrm{kg}^{-1}\right)$ for chickens fed high $\mathrm{K}$ level.

Carcass yield, nitrogen balance and excreta dry matter. Supplementing the diet with $\mathrm{Na}$ increased the carcass yield of the $\mathrm{Na}^{+} \mathrm{L}$ or adequate $\left(\mathrm{Na}^{+} \mathrm{A}\right)$ dietfed chickens, when compared to the $\mathrm{Na}^{+} \mathrm{VL}$ diet. A similar, but statistically unconfirmed, tendency was found in the case of added K. Both effects were probably the result of electrolyte influence on chicken performance and, above all, on body weight gain changes.

In the balance estimations presented in our experiment, the daily intake of 
nitrogen grew when the dietary $\mathrm{Na}^{+}$level increased from $0.94 \mathrm{~g}$ to $1.61 \mathrm{~g} \cdot \mathrm{kg}^{-1}$. Being a result of feed intake changes and nitrogen intake, nitrogen excretion grew in a similar manner. Nitrogen retention was not, in fact, affected, but as compared to $0.94 \mathrm{~g} \mathrm{Na} \cdot \mathrm{kg}^{-1}$ for the $\mathrm{Na}^{+} \mathrm{VL}$ diet, the proportion of $\mathrm{N}$ retained to $\mathrm{N}$ intake decreased when the dietary level of Na reached $1.61 \mathrm{~g} \cdot \mathrm{kg}^{-1}$. This result seems to be in agreement with Adekunmisi and Robbins' (1987) findings that Na bicarbonate supplementation might stimulate uric acid excretion through the kidneys.

The comparison of BWG, carcass yield and non significant tendency in nitrogen retention and breast meat and abdominal fat content confirmed negative effect of $0.94 \mathrm{~g} \cdot \mathrm{kg}^{-1} \mathrm{Na}$ content $(\mathrm{Na}+\mathrm{VL}$ treatment) on organism when chickens fed high $\mathrm{K}$ levels. This is a sign of the deficiency of mineral component, among other important for process of nutrients absorption in the gut (McDowell, 1992). It can indicate a positive effect of enlarged dietary $\mathrm{Na}$ content to $1.25 \mathrm{~g} \cdot \mathrm{kg}^{-1}$ on growth and body composition and also, as a non significant tendency, on nitrogen retention. A positive effect of $\mathrm{NaHCO}_{3}$ supplement to the diet on carcass weight and dressing percentage of chickens was reported by Ahmad et al. (2005).

Potassium may increase water intake and excreta moisture (Vieira and Lima, 2005) in broiler chickens. In our experiment, the $\mathrm{K}$ content in the basal non supplemented diet was relatively high and negatively affected the dry matter content of excreta. The $\mathrm{K}$ added to the basal diet increased that effect; in particular, a dietary $12.5-12.7 \mathrm{~g} \cdot \mathrm{kg}^{-1}$ decreased the dry matter content in excreta to $15-16 \mathrm{~g} \cdot \mathrm{kg}^{-1}$, for both feeding periods. In layer diets, dietary $\mathrm{K}$ levels were elevated from $2.3 \mathrm{~g}$ to $20{\mathrm{~g} \cdot \mathrm{kg}^{-1}}$ in the diet (Smith et al., 2000). They calculated that each $1 \mathrm{~g}$ increase of $\mathrm{K}$ caused a $1.2 \%$ increase of moisture content in excreta.

Among other factors that may affect litter moisture, increased water consumption is probably the primary one. Oviedo-Rondon et al. (2001) reported that, at higher levels of $\mathrm{Na}^{+}$in the diet, or given an excess of that electrolyte, $\mathrm{Na}$ might also increase litter moisture. In contrast, being at the lower limit of Na requirements for the diet $\left(\mathrm{Na}^{+} \mathrm{VL}\right)$, the $\mathrm{Na}$ levels used in our experiment did not affect the dry matter content in excreta.

\section{CONCLUSIONS}

The results of the experiment presented here suggest that at high level of $\mathrm{K}$ in the diet, and moderate level of $\mathrm{Cl}\left(1.73 / 1.89 \mathrm{~g} \cdot \mathrm{kg}^{-1}\right)$, the $\mathrm{Na}$ requirement for adequate chicken performance could be moderate and equal 1.2-1.7/1.25$1.6 \mathrm{~g} \cdot \mathrm{kg}^{-1}$ in the first/second period of feeding. Established Na requirement is the result of proportion between high dietary level of $\mathrm{K}$ and moderate level of $\mathrm{Cl}$ and is connected with the relatively high sum of cations and low $\mathrm{Na}: \mathrm{K}$ ratio. Interaction 
between dietary $\mathrm{Na}$ and $\mathrm{K}$ levels for body weight gain and other indices of performance, and for nitrogen retention, suggest a reciprocal relationship between both electrolytes in the diet.

\section{REFERENCES}

Adekunmisi A.A., Robbins K.R., 1987. Effect of dietary crude protein, electrolyte balance, and photoperiod on growth of broiler chickens. Poultry Sci. 66, 299-305

Ahmad T., Sarwar M., Mahr-Un-Nisa, Ahsan-Ul-Haq, Zia-Ul-Hasan, 2005. Influence of varying sources of dietary electrolytes on the performance of broilers reared in a high temperature environment. Anim. Feed Sci. Tech. 20, 277-298

AOAC, 1990. Association of Official Analytical Chemists, Official Methods of Analysis. $15^{\text {th }}$ Edition. Arlington, VA

Becker M., Harnisch S., 1958. Neue Untersuchungen über die Gültigkeit und Exagktheit von Stickstoffbilanzen bei Stoffwechselversuchen an lebenden Tieren. Arch. Tierernähr. 8, 401- 419

Borgatti L.M.O., Albuquerque R., Maister N.C., Souza L.W.O., Lima F.R., Trindade Neto M.A., 2004. Performance of broilers fed diets with different dietary electrolyte balance under summer conditions. Braz. J. Poultry Sci. 6, 153-157

Borges S.A., Fisher Da Silva A.V., Maiorka A., 2007. Acid-base balance in broilers. World Poultry Sci. J. 63, 73-81

European Table of Energy Values for Poultry Feedstuffs, 1989. WPSA, Wageningen (The Netherlands)

ISO 6869, 2000. Determination of the Content of Ca, Cu, Fe, Mg, Mn, K, Na, Zn Using Method of Atomic Absorption Spectrometry

Johnson R.J., Karunajeewa H., 1985. The effects of dietary minerals and electrolytes on the growth and physiology of the young chick. J. Nutr. 115, 1680-1690

McDowell L.R., 1992. Minerals in Animal and Human Nutrition. Academic Press Inc. New York, pp. 78-97

Mongin P., 1981. Recent advances in dietary anion-cation balance applications in poultry. Proc. Nutr. Soc. 40, 285-294

Murakami A.E., Oviedo-Rondo E.O., Martins E.N., Pereira M.S., Scapinello C., 2001. Sodium and chloride requirements of growing broiler chickens (twenty-one to forty-two days of age) fed corn-soybean diets. Poultry Sci. 80, 289-294

Murakami A.E., Saleh E.A., England J.A., Dickey D.A., Watkins S.E., Waldroup P.W., 1997. Effect of level and source of sodium on performance of male broilers to 56 days. J. Appl. Poultry Res. 6, 128-136

NRC, 1994. Nutrient Requirements of Poultry. National Research Council. $9^{\text {th }}$ Edition. National Academy Press. Washington, DC

Oliveira J.E., Albino L.F.T., Rostagno H.S., Paez L.E., Carvalho D.C.O., 2005. Dietary levels of potassium for broiler chickens. Braz. J. Poultry Sci. 7, 33-37

Oviedo-Rondon E.O., Murakami A.E., Furlan A.C., Moreira I., Macari M., 2001. Sodium and chloride requirements of young broiler chickens fed corn-soybean diets (one to twenty-one days of age). Poultry Sci. 80, 592-598

Smith A., Rose S.P., Wells R.G., Pirgozliev V., 2000. Effect of excess dietary sodium, potassium, calcium and phosphorus on excreta moisture of laying hens. Brit. Poultry Sci. 41, 598-560 
Vieira S.L., Lima I.L., 2005. Live performance, water intake and excreta characteristics of broilers fed all vegetable diets based on corn and soybean meal. Internat. J. Poultry Sci. 4, 365-368

Volhard J., 1874. Über eine neue Methode der Massanalytischen Bestimmung des Silbers. J. Pract. Chem. 9, 217- 224

Ziołecki J., Doruchowski W., 1989. The Method for Evaluation of Poultry Carcass (in Polish). Editor: COBRD, Poznań, pp. 1-30 